\title{
Handmade cloned bovine embryos, parthenogenesis and in vitro fertilization: a comparison
}

\section{Clonación manual de embriones bovinos, partenogénesis y fertili- zación in vitro: una comparación}

\author{
N. A. Gómez*, M. M. Ramírez' y Z. T. Ruiz-Cortés'
}

\begin{abstract}
The handmade cloning and parthenogenesis as a control leads to the possibility of studying biological processes such as cell reprogramming, epigenetics, embryo genome activation and preand post-natal development. The objective of this study was to standardize the process the handmade cloning (HCM) and to compare the resultant embryo production with parthenogenesis and in vitro fertilization (IVF). The primary fibroblast culture was established from explants of ear, the manual cloning technique was standardized with this fibroblast and 10 processes to cloning, parthenogenesis and fertilization in vitro were performed, and the compared production and embryo quality was performed by an ANOVA. An in vitro culture of fibroblast cells was established with optimal characteristics, allowing the genetic material to be used in the process of cloning. The parthenote group without zona pellucida ( $\mathrm{ZP}$ ) exhibited a higher cleavage rate compared with the other groups of parthenotes with ZP and IVF embryo $(\mathrm{p}<0.05)$. The number of blastomeres was greater in the IVF $(109.81 \pm 11.70)$ compared with the parthenote with ZP (73.73 \pm 7.09$)$, without ZP (78.16 \pm 7.65$)$ and clone (CL, 77.5 \pm 8.23$)$ groups. Embryo production in the CL, ZP, without ZP and IVF groups was not significantly different $(29.7,37.6,33.8$ and $35.2 \%$ respectively). The HCM technique was successfully standardized in the laboratory. The resultant embryo production was similar between handmade cloned embryos, parthenogenesis and in vitro fertilization. The findings of this work give rise to different routes for studying embryology and contribute to the optimization of this technique for commercial purposes.
\end{abstract}

KEYWORDS

cloning $\cdot$ parthenote $\cdot$ fibroblast

\section{INTRODUCTION}

The most popular method used to create clones is somatic cell nuclear transfer (SCNT), which

\section{RESUMEE}

Los procesos de clonación y controles partenogenéticos se presentan como una herramienta para el estudio de procesos biológicos, tales como reprogramación celular, epigenética, activación del genoma embrionario y crecimiento pre y posnatal. El objetivo de esta investigación fue estandarizar el proceso de clonación manual (CM) en condiciones locales y comparar tasas de producción y calidad embrionaria entre clones y embriones obtenidos por partenogénesis $\mathrm{y}$ fertilización in vitro (FIV) en bovinos. El cultivo primario de fibroblastos se estableció a partir de explantes de oreja, con dichos fibroblastos se estandarizó la técnica de clonación manual y se realizaron 10 procedimientos de clonaje, partenogénesis y fertilización in vitro, la comparación de la producción y calidad embrionaria se realizó por medio de un ANOVA. Se obtuvo un cultivo de fibroblastos con características óptimas para ser usados como donantes del material genético necesario para el proceso de clonación. El grupo partenotes sin zona (PSZP) tuvo un mayor clivaje comparado con los demás grupos $(\mathrm{p}<0,05)$. La producción de blastocistos entre clones $\mathrm{CL}$, partenotes con zona PCZP, PSZP y FIV no presentó diferencia estadísticamente significativa $29,7,37,633,8 \%$ y $35,2 \%$ respectivamente. El número de blastomeras fue mayor para el grupo FIV $(109,81 \pm 11,70)$ con respecto a PCZP $(73,73 \pm 7,09)$, PSZP $(78,16 \pm 7,65)$ y CL $(77,5 \pm 8,23)$. Se estandarizó la técnica de CM y se obtuvo una tasa de producción similar en todos los grupos, lo que abre posibilidades infinitas de investigación para el entendimiento de procesos biológicos de desarrollo embrionario, además de contribuir a la optimización de la técnica con fines comerciales.

\section{Phlabras Clave \\ clonación · partenoto ·fibroblasto}

requires the use of micromanipulators, qualified personnel, and large investments in equipment (Wilmut et al., 2002, Lewis et al., 2005). New methods for cloning have been developed with

\footnotetext{
'Biogenesis Research Group, School of Agricultural Sciences, University of Antioquia. Carrera 75 N 65-87, Bloque 46-202, AA 1226, Medellín - Colombia. E-mail: biogenesis1995@gmail.com

*Autor de correspondencia: nataliagomezmo@gmail.com
} 
the aim of increasing the use of this methodology and decreasing the costs associated with it, leading to a technique known as manual cloning (MC). The advantage of $\mathrm{MC}$ is that it can be performed without the use of micromanipulators for the enucleation and transfer of donor cells (Vajta and Gjerris, 2006).

Both HMC and SCNT result in acceptable rates of embryonic production, similar to those obtained through in vitro fertilization (IVF) (Campbell, 2007). Nevertheless, the percentages of bovine pregnancy and live births achieved using these techniques are still very low (Paterson et al., 2003; Rodriguez-Osorio et al., 2012). As a result, the scientific community has stressed the need to understand the diverse factors that affect these processes, resulting in wide ranging efforts to simplify and standardize cloning techniques.

One of the factors that most significantly affects the success of cloning is the type, lineage, and condition of the nuclear donor cell (Galli et al., 2004; Powell et al., 2004; Hoffert et al., 2005). The fibroblasts are most often used in mammalian cloning due to the ease of their collection and propagation (Oback and Wells, 2007). It is of the utmost importance that each laboratory that seeks to standardize and establish cloning protocols has a clear understanding of all of those factors.

In the MC the oocytes are highly manipulated and subjected to processes that can run counter to their cellular viability. It is therefore critical to apply parallel techniques, such as the production of parthenogenetic embryos, ultimately resulting in control over the quality of the selected oocytes and their capacity to be chemically activated and to allow early embryonic development (Kharche and Birade, 2013).

Due to the relative ease of execution and low cost of $\mathrm{MC}$, this technique has been proposed as a desirable alternative to research cloning in Colombia, and its future implementation at the commercial level has been suggested. The objectives of this study were to establish the conditions and standardize the protocols necessary for performing manual cloning in Colombia and to compare production rates and embryonic quality between embryos produced through MC against those obtained via in vitro fertilization and through parthenogenesis.

\section{MATERIALS AND METHODS Location}

Samples were collected in the slaughter house facility, located in the town of Bello - Antioquia; live animals were not manipulated in this process. All the procedures were performed in the embryology laboratory Biogenesis research group at the Antioquia University.

\section{Generation of primary cultures of fibroblasts}

Fifteen heifers' ears were recovered from a local animal slaughter house. The tissues were transported in PBS with a $10 \%$ solution of streptomycin-penicillin-gentamicin (SPG). After washing and plucking each of the ears, the tissue was cut into slices ( $\sim 3 \mathrm{~mm}$ thick), transferred to a 6-well plate (4-5 slices per well) containing $1 \mathrm{~mL}$ of DMEM (Dulbecco's Modified Eagle Medium) culture medium supplemented with $10 \%$ fetal bovine serum (FBS, Gibco, NY, USA) and 1\% SPG. The slices were incubated at $38.8^{\circ} \mathrm{C}$ under $5 \% \mathrm{CO}_{2}$ and $90 \%$ relative humidity. When plates reached $>90 \%$ confluence, which occurred approximately 2 weeks after culturing, the explants were removed, and the cells were detached using $0.25 \%$ trypsin and $5 \mathrm{mM}$ EDTA for 2-3 minutes. The cells were then transferred to a T25 culture flask and were frozen in medium composed of DMEM supplemented with 20\% SBF and $10 \%$ DMSO in $0.25 \mathrm{~mL}$ straws at a concentration of 30.000 cells/straw for later reconstruction via $\mathrm{MC}$. The straws were then stored in liquid nitrogen $\left(-196^{\circ} \mathrm{C}\right)$ (Figure 1).

\section{Cellularviability.}

During the transfer and freezing-unfreezing process, cellular viability was determined using $0.4 \%$ trypan blue in a $1: 1$ solution. The number of living (unstained) and dead (stained) cells was evaluated (Freshney, 2005; Hall et al., 2006).

\section{Standardizing manual cloning}

\section{In vitro maturation (IVM)}

Oocytes were aspirated from ovaries of cows sacrificed at a local animal processing plant. The ovaries were transported in sterile $0.9 \%$ saline solution at $30^{\circ} \mathrm{C}$. Follicles between 2 and $7 \mathrm{~mm}$ in diameter were aspirated with an 18-gauge needle. The follicular liquid was placed in $15 \mathrm{~mL}$ conical tubes and was allowed to decant for 20 minutes. Cumulus-oocyte complexes (COCs) with homogenous ooplasm, round morphology, and a minimum of three layers of flattened granulosa cells were selected for in IVM. Maturity was carried out in $70 \mu \mathrm{L}$ of TCM-199 maturation medium supplemented with $10 \%$ FBS, $24.9 \mathrm{mM}$ pyruvate, $1 \mu \mathrm{g} / \mathrm{mL} \mathrm{LH}$ and 20 $\mu \mathrm{g} / \mathrm{mL}$ FSH. Twelve oocytes were placed in each drop and were incubated under $5 \% \mathrm{CO}_{2}$ at $38.8^{\circ} \mathrm{C}$ 
and $90 \%$ humidity for 20 hours.

After 20 hours, cumulus expansion was evaluated visually, and two groups of cells were retrieved to initiate parthenogenesis and cloning. The remaining oocytes were inseminated as stated below.

\section{In vitro fertilization (IVF)}

Cryopreserved semen from a single bull was used for all replicates, it was thawed in water at $35^{\circ} \mathrm{C}$ for one minute, then placed in sperm-TALP medium (Parrish et al., 1988) and centrifuged to remove the excess freezing diluent. The sample was re-suspended in fertilization medium (fertTALP) supplemented with $12 \mu \mathrm{L} / \mathrm{mL}$ heparin, 45 $\mu \mathrm{L} / \mathrm{mL}$ PHE (penicillamine-hypotaurineepinephrine), and $24.9 \mathrm{mM}$ pyruvate and then centrifuged a second time. After adjusting the final concentration to $1-2 \times 10^{6}$ spermatozoa $/ \mathrm{mL}$, a $10 \mu \mathrm{L}$ aliquot was deposited in each $50 \mu \mathrm{L}$ drop of fert-talp medium containing oocytes.

\section{Parthenogenesis}

A portion of the mature oocytes (20-50/per replicated) possessing polar bodies (PB) but lacking cumulus cells were selected. The oocytes were divided into two groups. The first was deposited in drops of base medium (TCM199 Sigma M-2520 + $2.63 \mathrm{mM} \mathrm{NaHCO}+24.9 \mathrm{mM}$ pyruvate $+10 \%$ FBS +1 X Penicillin / streptomycin) (BM) for six hours. The second group was placed in drops of $\mathrm{BM}$ plus $0.5 \%$ pronase-E (protease) in serum-less BM plus $0.01 \%$ PVA (Polyvinyl alcohol); to degrade the ZP, the oocytes were removed from this medium when 20 to $30 \%$ showed thinning or deformation at the zona. Both groups were chemically activated in drops of BM containing $5 \mathrm{mM}$ ionomycin for 5 min, then incubated in CR2 medium with $2 \%$ FBS, $0.3 \%$ BSA and $2 \mathrm{mM}$ 6-dimethylaminopurine (6-DMAP) under oil for 4 hours and transferred to culture in vitro. The parthenotes lacking a zona pellucida were cultivated under the "well of the well" (WOW) system and were prepared with a 4-well plaque containing $400 \mu \mathrm{L}$ of CR2 medium and $200 \mu \mathrm{L}$ of mineral oil in each well; small punctures were made at the bottom of each well to create the microwells. The parthenotes with a zona pellucida were cultivated in a well containing only CR2 medium.

\section{Obtaining cytoplasts}

Twenty hours after IVM, the COCs were stripped using a soft pipette. Oocytes in which the first PB had already divided out were selected and washed in drops of BM. The oocytes were then incubated for one hour in drops of BM plus 10 $\mathrm{g} / \mathrm{mL}$ demecolcine to induce nuclear protrusion and perform enucleation. The $\mathrm{ZP}$ was removed by exposing the oocytes to $0.5 \%$ pronase in serum-less BM plus $0.01 \%$ PVA. A total of 1 to 2 oocytes lacking the ZP were placed in microdrops of $5 \mu \mathrm{L}$ of BM plus $5 \mathrm{mg} / \mathrm{ML}$ cytochasalin B (CCB) covered in mineral oil (60-80 drops/plaque). The oocytes were divided based on the visualization of protrusion, attempting to remove as little cytoplasm as possible. Division was performed with an Ultra Splitting Sharp blade (Bioniche, Montréal, QC, Canada) (Figure 2).

\section{Embryonic reconstruction}

A $100 \mathrm{~mm}$ Petri dish was prepared with 4-5 drops of BM and 3 drops of serum-less BM and 500 $\mu \mathrm{g} / \mathrm{mL}$ PHA (phytohemagglutinin). One drop of $\mathrm{BM}$ received approximately 10 cytoplasts, while another received the fibroblast suspension previously subjected to treatment with $0.25 \%$ trypsin and washed with BM. A total of 4-6 cytoplasts were transferred to a drop of PHA, 2-3 of which were later transferred to the cellular suspension, where a sealed capillary tube was used to carefully guide each cell toward a single round cell (fibroblast) until they merged. The cells were subsequently returned to the drop of PHA, where each duet (cytoplast-cell) was deposited close to a single cytoplast until a triplet was formed (cytoplast-cell-cytoplast) (Figure 2).

\section{Electrofusion and activation}

Each triplet (cytoplast-cell-cytoplast) was horizontally oriented in a BLS fusion chamber (GSS-250, $250 \mu \mathrm{m}$ distance between electrodes) covered in ME (fusion medium). Two $1 \mathrm{kV} / \mathrm{cm}$ square-wave pulses were administered at 20 $\mu \mathrm{s} /$ pulse to fuse the membranes using a BLS CF.150B electrofusor. The presumed zygotes were removed from the chamber, then washed in drops of BM and individually incubated in $\sim 5 \mu \mathrm{L}$ drops of BM under mineral oil for 30 to 45 minutes; the fusion rates were evaluated visually by verifying the formation of a single structure. Within 26-30 hours of the initiation of IVM, the presumed zygotes were activated chemically in the same way as in the parthenogenesis procedure (Figure 2).

\section{In vitro culture (ICV)}

After activation, the presumed zygotes were washed a number of times in CR2 culture medium containing $0.374 \mathrm{mM}$ pyruvate, $5 \%$ FBS 
and $50 \mathrm{mg} / \mathrm{mL}$ BSA and cultured using the WOW system. An embryo was deposited in each well and cultured at $38.8^{\circ} \mathrm{C}$ under $5 \% \mathrm{CO}_{2}$ and $90 \%$ relative humidity for 7 days (Figure 2 ).

\section{Evaluating development rates}

After 72 hours of culture, the rate of cleavage was visually evaluated, taking into account zygotes with as little as one division ( 2 cells). On day 7 , the embryo production rates of all four groups (clones, parthenotes with and without a zona pellucida and IVF embryos) were evaluated, taking into account the states of development from the morula to the expanded blastocyst. The states of development and the quality of embryo morphology were evaluated according to the guidelines of the IETS (Stringfellow and Seidel 1998) (Figure 3).

Staining to determine number of blastomeres. Embryos from all groups were fixed in $70 \%$ alcohol and subjected to staining with $10 \mu \mathrm{g} / \mathrm{mL}$
Hoechst stain for $5 \mathrm{~min}$ to determine the total number of blastomeres. Counting was performed under a Zeiss fluorescent microscope. To minimize error, two researchers performed the procedure twice each, and their values were averaged to provide a blastomere count for each embryo (Figure 4).

Unless otherwise specified, all of the reagents listed above were from SIGMA Aldrich, St. Louis, MO, USA.

\section{Data analysis}

The Saphiro-Wilk and Levene tests were used to check for normality and homogeneity of variance, respectively; post hoc ANOVA was performed to determine differences in the average percentages of cleavage, number of embryos, and number of cells among the clones, parthenotes, and IVF embryos. The data were analyzed with IBMSPSS Statistics version 22.0.
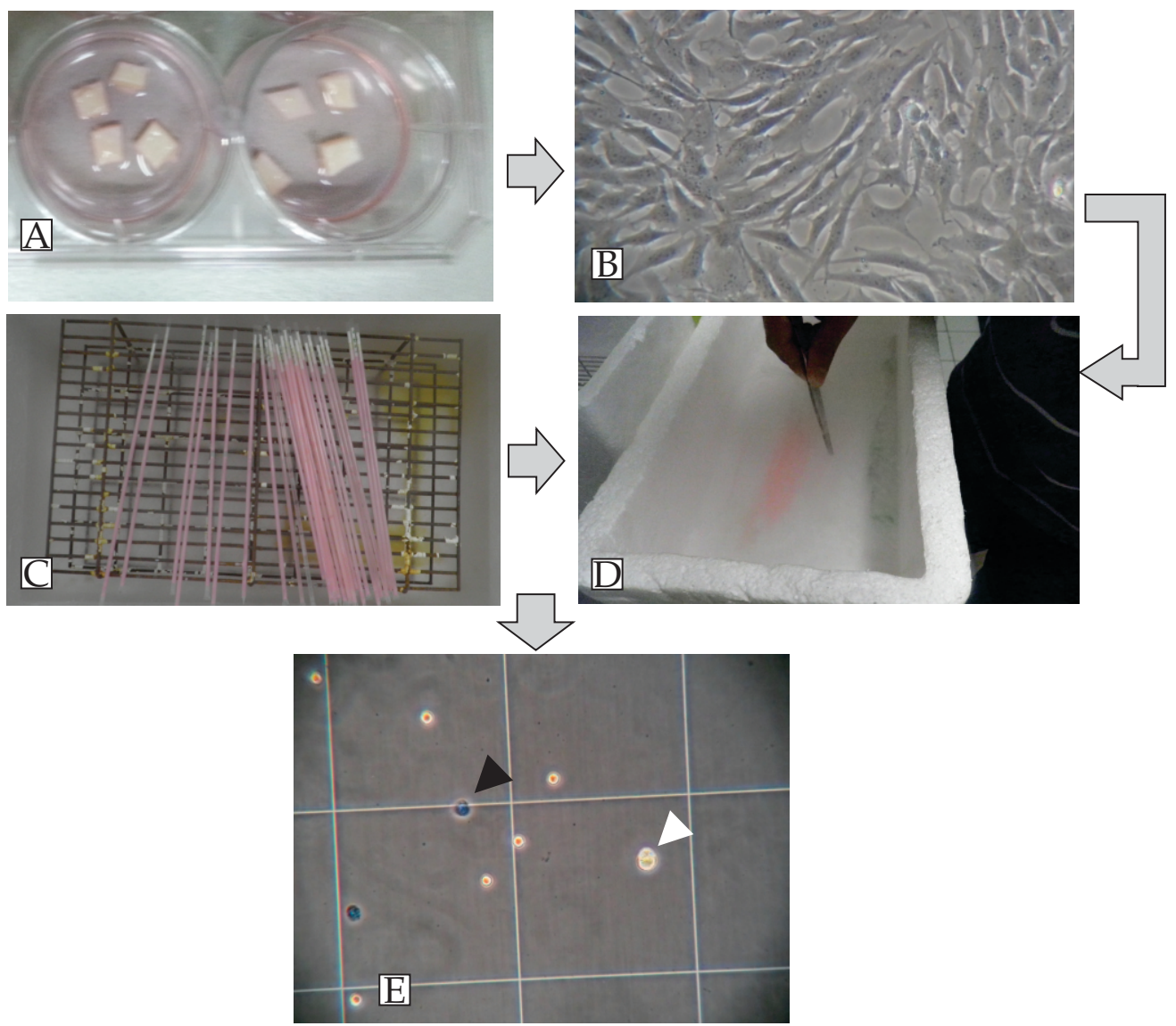

Figure 1. Primary fibroblast culture. A. Explant culture of bovine ear cartilage, sliced at a thickness of $\sim 3 \mathrm{~mm}$. B. 40X magnification of a bovine fibroblast culture. C-D. Freezing the fibroblasts using $0.25 \mathrm{~mL}$ straws. E. Visual evaluation using trypan blue (the white arrow indicates a living cell and the black arrow a dead cell).

Figura 1. Cultivo primario de fibroblastos. A. Cultivo explante de cartílago de oreja bovina, partes de $\sim 3 \mathrm{~mm}$ de espesor. B. Cultivo de fibroblastos bovinos, magnificación 40X. C-D. Congelación de fibroblastos bovinos usando pajuelas de $0.25 \mathrm{~mL}$ E. Evaluación visual, usando azul de tripano (la flecha blanca indica una célula viva y la flecha negra una célula muerta). 


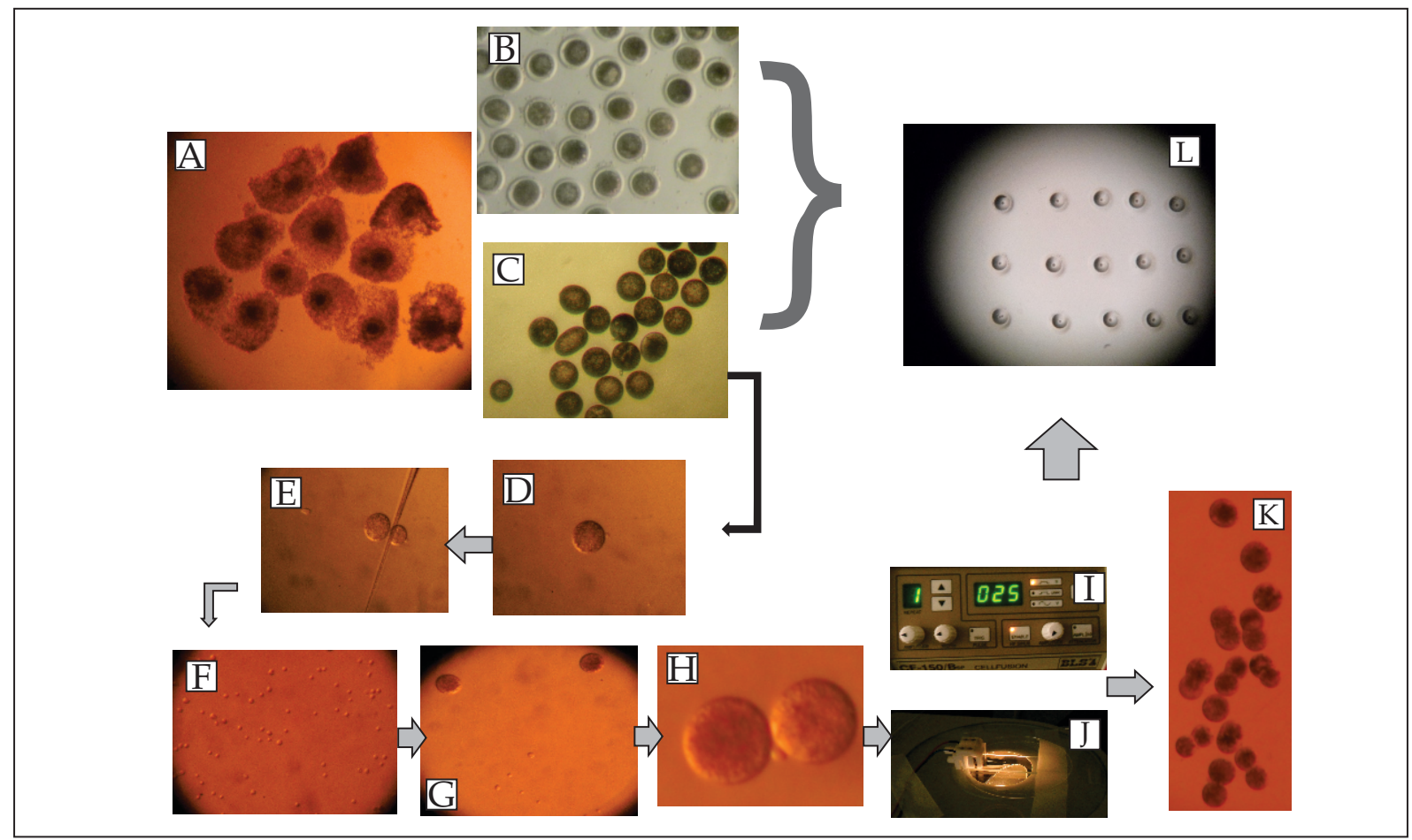

Figure 2. Standardizing the manual cloning process. A. Oocytes $20 \mathrm{~h}$ after the initiation of IVM. B. Stripped oocytes. C. Oocytes with no zona pellucida. D-E. Enucleation. F. Nuclear donor fibroblasts. G-H. Reconstruction. H: Triplet (cytoplast-cellcytoplast). I-J. Electrofusion. K. Triplet Fusion. The bracket indicates the transition to culture.

Figura 2. Estandarización del proceso de clonación manual. A. Oocitos después de 20 h de la iniciación de la MIV. B. Oocitos sin células de la granulosa. C. Oocitos sin zona pelúcida. D-E. Enucleación. F. Fibroblastos donantes de núcleo. G-H. Reconstrucción. H: Tripleta (citoplasto-célula-citoplasto). I-J. Electrofusión. K. Fusión de la tripleta. El corchete indica el paso al cultivo.

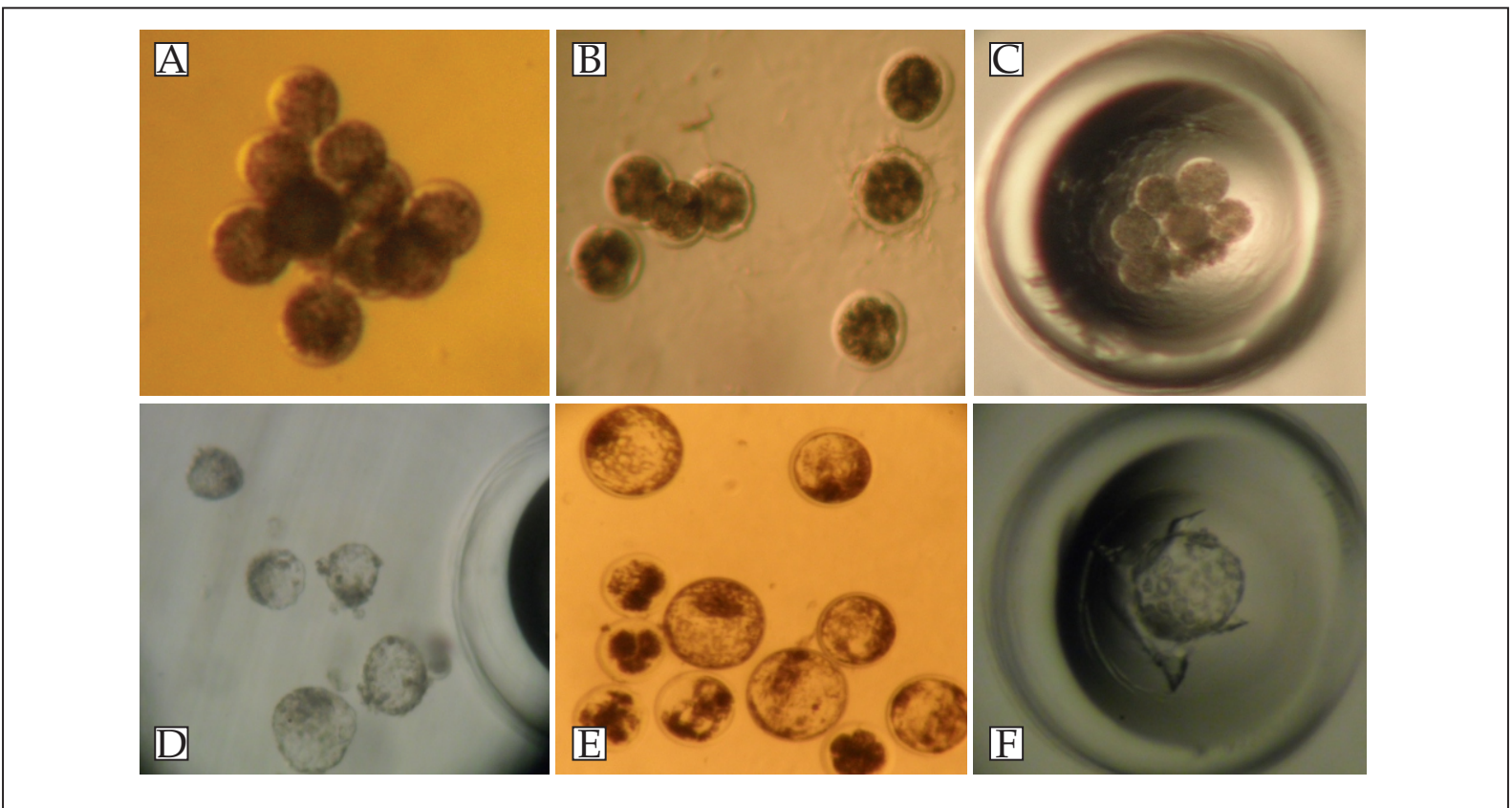

Figure 3. Cleavage and production of embryos. A. Clone cleavage. B. Cleavage of parthenotes with a ZP. C. Cleavage of parthenotes lacking a ZP. D. Cloned embryos outside of microwells. E. Parthenogenetic embryos with a ZP. F. Parthenogenetic embryos lacking a ZP.

Figura 3. Clivaje y producción de embriones. A. Clivaje de un clon. B. Clivaje de un partenoto con ZP. C. Clivaje de un partenoto sin ZP. D. Embriones clonados fuera de los micropocillos. E. Embriones partenogenéticos con ZP. F. Embriones partenogenéticos $\sin \mathrm{ZP}$. 

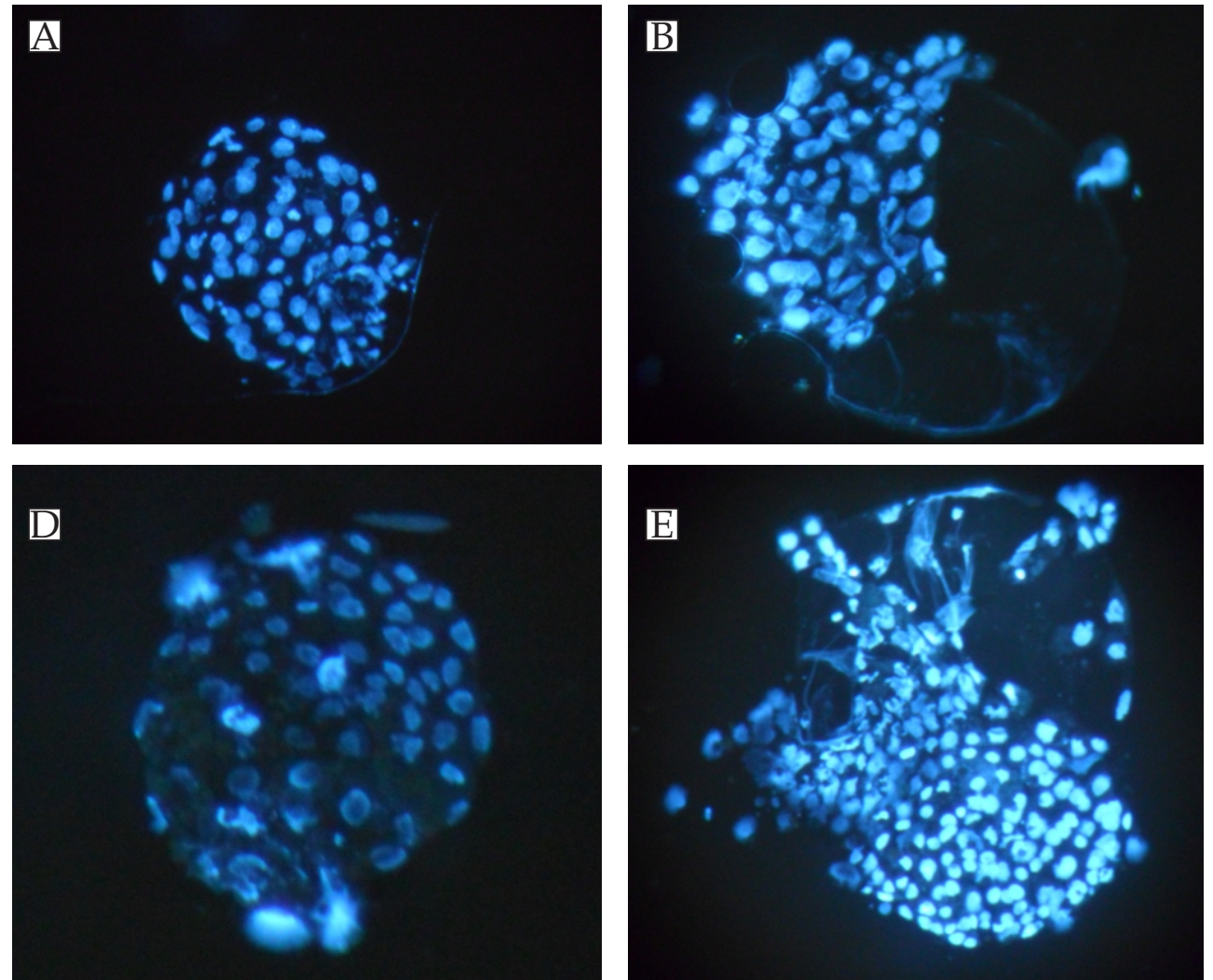

Figure 4. Evaluation of cell numbers via fluorescent Hoechst staining. A. Cloned embryo. B. Parthenogenetic embryo with a ZP. C. Parthenogenetic embryo lacking a ZP. D. Embryo produced through IVF. All panels are at $10 \mathrm{X}$ magnification.

Figure 4. Evaluación del número de células por fluorescencia, tinción con Hoechst. A. Embrión clonado B. Embrión partenogenético con ZP. C. Embrión partenogenético sin ZP. D. Embrion producido por fertilización in vitro FIV. Magnificación 10X.

\section{RESULTS}

\section{Primary cell culture}

After creating 15 sets of heifer ear cartilage explants over six months, a culture of viable fibroblasts to be used as nuclear donors for the MC procedure was produced. The cells were able to be stored by freezing with DMSO in liquid nitrogen until they were needed for the cloning procedure.

\section{In vitro embryo production}

In the Table 1 provides a summary of the in vitro embryo development observed over 7 days. Cleavage in the group of parthenotes with no zona pellucida was significantly different from that in the other groups (cloned embryos, parthenotes with a zona pellucida, and IVF embryos). There was no significant difference in the percentages of embryos produced among the groups.

Table 1. Development of bovine embryos produced through manual cloning, parthenogenesis and in vitro fertilization Tabla 1. Desarrollo de embriones bovinos producidos mediante clonación manual, partenogénesis y fecundación in vitro

\begin{tabular}{lccc}
\hline Groups & $\begin{array}{c}\text { N. Oocytes / Oocytes } \\
\text { reconstructed }\end{array}$ & Cleavage (\%) & $\begin{array}{c}\text { Production of } \\
\text { embryos (\%) }\end{array}$ \\
\hline Clones & 165 & $76.73 \pm 4.58^{\mathrm{b}}$ & $29.72 \pm 3.14$ \\
Parthenotes with zone & 201 & $75.23 \pm 3.32^{\mathrm{b}}$ & $37.64 \pm 2.76$ \\
Parthenotes without zone & 187 & $89.37 \pm 2,64^{\mathrm{a}}$ & $33.88 \pm 3.04$ \\
IVF & 898 & $75.32 \pm 2.41^{\mathrm{b}}$ & $35.22 \pm 2.79$ \\
\hline
\end{tabular}

a,b Different letters between the rows indicate statistically significant difference $\mathrm{p}<0.05$ 


\section{Embryo quality}

A total of 56 embryos were processed and analyzed to determine the total number of blastomeres. The average number of cells per embryo in each group is shown in Table 2. The number of blastomeres in the IVF group was statistically significantly different with respect to the other groups.

Table 2. Embryo quality. Number of cells per embryo produced through manual cloning, parthenogenesis and in vitro fertilization.

Tabla 2. Calidad del embrión. Número de células por embrión producido mediante clonación manual, partenogénesis y fecundación in vitro.

\begin{tabular}{lc}
\hline \multicolumn{1}{c}{ Groups } & $\begin{array}{c}\text { Promedio de } \\
\text { blastomeras }\left(\mathbf{n}^{\circ}\right)\end{array}$ \\
\hline Clones & $77.5 \pm 8.23^{\mathrm{a}}$ \\
Parthenotes with zone & $73.73 \pm 7,09^{\mathrm{a}}$ \\
Parthenotes without zone & $78.16 \pm 7.65^{\mathrm{a}}$ \\
IVF & $109.81 \pm 11.70^{\mathrm{b}}$ \\
\hline
\end{tabular}

\section{DISCUSSION}

Individual laboratory conditions and in vitro production systems can influence parameters such as morphology, physiology, and development in both clones and IVF embryos (Farin et al., 2004; Vatja and Gjerris 2006) According to the results of the present study, we achieved standardization in the production of clones through manual cloning, or "handmade cloning", under specific local conditions, from the creation and storage of primary fibroblast cultures to obtaining viable transferable blastocysts.

The first phase of this standardization process consisted of obtaining cultures of somatic cell nucleus donors. Fibroblasts were chosen for this purpose due to the ease of obtaining them and their high in vitro proliferation. To date, viable offspring have only be produced from 12 types of differentiated tissues, even though over 200 cells donors types exist in mammals (Oback and Wells, 2007) Somatic cells have been obtained from various organs and cells, such as mammary glands, cumulus cells, oviducts, ears, skin, muscles, livers, tails, and Sertoli cells (Campbell, 2007). These various types of tissue appear to present differences in offspring generation. Fibroblasts are the most commonly used cells in mammalian cloning, as they are unspecialized mesenchymal cells capable of extensive proliferation, tissue repair, and differentiation into a variety of other connective tissues, such as bone, cartilage, and muscle (Oback and Wells, 2007; Daniel et al., 2008). The use of these cells has also become widespread due to the ease of their collection and propagation in culture.

Parthenogenetically activated embryos serve as a good control for the in vitro system of production, emphasizing the use of suitable media to satisfy their nutritional needs during the different stages of the development of presumed zygotes and future embryos. In this study, the parthenogenetic embryos whose zona pellucida was removed before activation showed a significant increase in their percentage of cleavage relative to embryos that retained the zona, cloned embryos, and in vitro fertilized embryos $(p<0.05)$, though this did not have an effect on subsequent blastocytic development.

These results are not consistent with other studies, in which there were no significant differences in the kinetics of development observed during the first rounds of cleavage (Paffoni et al., 2008; Miyauchi, 2012). However, it has been suggested that the first divisions after activation of the oocyte depend specifically on the content inherited by the oocyte, with little participation from the spermatozoon. In another study, Gomez et al. (2009) contrary to what was reported here, a significant difference was found in the rate of initial development in embryos produced using IVF, suggesting that many biological aspects of parthenogenetic embryos are still unknown, constituting a potential subject for future research.

One of the more interesting results of the present study was the observed percentage of bovine clone embryo production, as a higher percentage of blastocytes was obtained compared with other studies (29\% vs. 19\%) (Forell, 2008). This percentage was not statistically significantly different from that in the group of embryos generated through in vitro fertilization, which was between 30 and $35 \%$, typical of commercial levels (Barreto de Almeida, 2008). This comparison represents an important finding, as there are few studies that have compared cloning techniques with IVF, which has been used successfully at the commercial level for many years.

Determining the number of cells that make up the embryo (blastomere) is usually considered indicative of the quality and viability of the embryo. Human studies suggest that the cellular mass that forms the blastocyst is indicative of its implantation potential (Dumoulin et al., 1999). In the present study, the number of blastomeres in the blastocytes formed following IVF was significantly greater than in the embryos activated parthenogenetically and in the cloned embryos (109.8 vs. 73.7,78.1 and 77.5). The observed values 
are equivalent to or greater than those obtained in other studies in both in vitro fertilized embryos and cloned bovine embryos (Totey et al., 1996; Figueiró et al., 2002). This indicates that the applied system of production is efficient in both the production of blastocytes and the obtained embryo quality, defined based on the number of blastomeres (Im et al., 2006). The smaller number of blastomeres found in parthenogenetic embryos and clones could be due to their requiring a greater number of or additional nutrients in the developmental media. Another possibility is that the greater amount of manipulation the oocytes undergo during the procedure, as they are exposed to high stress conditions (protein degradation, cytoplasm removal, exposure to different chemical components and electrical shock), could be detrimental to their development and might be reflected in the lower number of blastomeres in these embryos.

Although the primary objective of this study was to use parthenogenetic embryos as the control for measuring the quality of cloning, the results produced in the group of embryos generated using parthenotes lacking the zona pellucida paves the way for future research on embryo quality, such as that reported recently (Hirayama et al., 2014). This study demonstrated that the transfer of embryos fertilized in vitro, along with parthenogenetic embryos, could aid in maternal recognition, with increased INT-tau production being observed until day 40 of gestation, in addition to generating investigations into MC transgenesis, such as that conducted in goats (Pereira et al., 2013) The in vitro production of bovine embryos has become a pioneering biotechnology for genetic improvement. However, due to pressure from various public and private institutions, there are few published reports with statistical validation, and research on this subject in some places like Colombia is scarce compared with other countries (Restrepo, 2008). As of this writing, there is only one available report on the cloning of buffalo using SCNT for commercial ends, which was performed in a different Colombian department (Santander). The authors reported a $23 \%$ pregnancy rate $(3 / 13$ clones transferred) for over sixty days with a perfect developmental state in April 2014.

\section{CONCLUSIONS}

As conclusions and future directions, it is proposed that manual cloning is an efficient and relatively simple alternative to traditional embryogenetic techniques that require the use of micromanipulators. This particular biotechnol- ogy provides promising prospects for molecular research on genetic reprogramming and for studying genetic expression, epigenetics, and optimization techniques for commercial and research goals (Taylor-Robinson et al., 2014).

This study contributes to the development of innovation, differentiation, and improvement processes at the level of assisted bovine reproductive biotechnologies, providing scientific support for increasing knowledge nationwide under local conditions. Additionally, these results demonstrate an efficient system, establishing the minimal conditions for performing $\mathrm{MC}$ and opening the door to future research into cloning.

In this regard, efforts to conduct new research into assisted reproductive biotechnologies should be directed toward optimizing existing procedures, for example, establishing somatic cell cultures from donor animals from whom biopsies are obtained in the field, perfecting oocyte maturation and enucleation processes for cloning and parthenogenesis, and improving fusion, activation, and culture temperature parameters for the embryos.

Future research directions could include studying why the presence of the zona pellucida or lack thereof influences embryo development in vitro, or why there are differences in gene expression that could influence the development of in vitro fertilized, parthenogenetically created (with or without zona pellucida), and cloned embryos. (Ganadero, 2014)

\section{FUNDING AND ACKNOWLEDGEMENTS}

We thank Colciencias, the Young Investigators and Innovators program, and Ganadería Rio Grande S.A.S for their participation in awarding the Young Investigator fellowship.

We also acknowledge the 2015-2016 Sustainability Strategy of the University of Antioquia, awarded to the Biogenesis Group.

\section{REFERENCES}

Almeida, A. B. D. (2008). Sistema biológico de aumento da taxa de prenhez. Embriões partenogenéticos podem ajudar o reconhecimento materno da gestação (Doctoral dissertation, Universidade de São Paulo).

Campbell, K. H. (2007). Ten years of cloning: questions answered and personal reflections. Cloning and stem cells, 9(1), 8-11.

Daniel, S. M., Raipuria, P., \& Sarkhel, B. C. (2008). Efficiency of cloned embryo production using different types of cell donor and electric fusion strengths in goats. Small 
Ruminant Research, 77(1), 45-50.

Dumoulin, J. C., Meijers, C. J., Bras, M., Coonen, E., Geraedts, J. P., \& Evers, J. L. (1999). Effect of oxygen concentration on human in-vitro fertilization and embryo culture. Human Reproduction, 14(2), 465-469.

Farin, C. E., Farin, P. W., \& Piedrahita, J. A. (2004). Development of fetuses from in vitro-produced and cloned bovine embryos. Journal of animal science, 82(13_suppl), E53-E62.

Figueiró, G. M., Fialho, S. S., Brum, D. D. S., Pasin, M., Rauber, L. P., Bernardi, M. L., ... \& Silva, C. A. M. (2002). Produção in vitro de embriões bovinos com soro de égua em diferentes fases do estro. Acta scientiae veterinariae. Vol. 30, n. 1,(2002), p. 1-8.

Forell, F. (2008). Otimização do sistema de produção de clones por transferência nuclear com a utilização de oócitos vitrificados e diferentes tipos celulares como doadores de núcleo. Acta Scientiae Veterinariae, 36(3), 315-316.

Freshney, R. I. (2005). Culture of specific cell types. John Wiley \& Sons, Inc.

Galli, C., Lagutina, I., \& Lazzari, G. (2003). Introduction to cloning by nuclear transplantation. Cloning $\mathcal{E}$ Stem Cells, 5(4), 223-232.

Gomez, E., Caamano, J. N., Bermejo-Alvarez, P., Carmen, D. Í. E. Z., Munoz, M., Martin, D., ... \& Gutierrez-Adan, A. (2009). Gene expression in early expanded parthenogenetic and in vitro fertilized bovine blastocysts. Journal of Reproduction and Development, 55(6), 607-614.

Hall, V. J., Ruddock, N. T., Cooney, M. A., Korfiatis, N. A., Tecirlioglu, R. T., Downie, S., ... \& French, A. J. (2006). Production of a cloned calf using zona-free serial nuclear transfer. Theriogenology, 65(2), 424-440.

Hirayama, H., Moriyasu, S., Kageyama, S., Sawai, K., Takahashi, H., Geshi, M., ... \& Matsui, M. (2014). Enhancement of maternal recognition of pregnancy with parthenogenetic embryos in bovine embryo transfer. Theriogenology, 81(8), 1108-1115.

Hoffert, K. A., Batchelder, C. A., Bertolini, M., Moyer, A. L., Famula, T. R., Anderson, D. L., \& Anderson, G. B. (2005). Measures of maternal-fetal interaction in day-30 bovine pregnancies derived from nuclear transfer. Cloning and stem cells, 7(4), 289-305.

Im, G. S., Seo, J. S., Hwang, I. S., Kim, D. H., Kim, S. W., Yang, B. C., ... \& Prather, R. S. (2006). Development and apoptosis of pre- implantation porcine nuclear transfer embryos activated with different combination of chemicals. Molecular Reproduction and Development, 73(9), 1094-1101.

Kharche, S. D., \& Birade, H. S. (2013). Parthenogenesis and activation of mammalian oocytes for in vitro embryo production: A review.

Lewis, I. M., French, A. J., Tecirlioglu, R. T., Vajta, G., McClintock, A. E., Nicholas, K. R., ... \& Trounson, A. O. (2005). Commercial aspects of cloning and genetic modification in cattle. Animal Production Science, 44(11), 1105-1111.

Miyauchi, T. A. (2012). Aspectos biológicos do desenvolvimento pré-implantacional de embriões bovinos partenogenéticos ou fecundados in vitro.

Oback, B., \& Wells, D. N. (2007). Donor cell differentiation, reprogramming, and cloning efficiency: elusive or illusive correlation?. Molecular reproduction and development, 74(5), 646-654.

Paffoni, A., Brevini, T. A. L., Gandolfi, F., \& Ragni, G. (2008). Parthenogenetic activation: biology and applications in the ART laboratory. Placenta, 29, 121-125.

Parrish, J. J., Susko-Parrish, J., Winer, M. A., \& First, N. L. (1988). Capacitation of bovine sperm by heparin. Biology of reproduction, 38(5), 1171-1180.

Paterson, L., DeSousa, P., Ritchie, W., King, T., \& Wilmut, I. (2003). Application of reproductive biotechnology in animals: implications and potentials: applications of reproductive cloning. Animal reproduction science, 79(3), 137-143.

Pereira, A. F., Feltrin, C., Almeida, K. C., Carneiro, I. S., Avelar, S. R. G., Neto, A. A., ... \& Bertolini, L. R. (2013). Analysis of factors contributing to the efficiency of the in vitro production of transgenic goat embryos (Capra hircus) by handmade cloning (HMC). Small Ruminant Research, 109(2), 163-172.

Powell, A. M., Talbot, N. C., Wells, K. D., Kerr, D. E., Pursel, V. G., \& Wall, R. J. (2004). Cell donor influences success of producing cattle by somatic cell nuclear transfer. Biology of reproduction, 71(1), 210-216.

Restrepo, G. (2008). Biotecnologias reproductivas aplicables a la produccion bovina en Colombia. Medellin: Libroarte.

Rodriguez-Osorio, N., Urrego, R., Cibelli, J. B., Eilertsen, K., \& Memili, E. (2012). Reprogramming mammalian somatic cells. The- 
riogenology, 78(9), 1869-1886.

Stringfellow, D. A., \& Seidel, S. M. (1998). Manual of the international embryo transfer society. The Society.

Taylor-Robinson, A. W., Walton, S., Swain, D. L., Walsh, K. B., \& Vajta, G. (2014). The potential for modification in cloning and vitrification technology to enhance genetic progress in beef cattle in Northern Australia. Animal reproduction science, 148(3), 91-96.

Totey, S. M., Daliri, M., Rao, K. A., Pawshe, C. H., Taneja, M., \& Chillar, R. S. (1996). Differential cleavage and developmental rates and their correlation with cell numbers and sex ratios in buffalo embryos generated in vitro. Theriogenology, 45(2), 521-533.

Vajta, G., \& Gjerris, M. (2006). Science and technology of farm animal cloning: state of the art. Animal reproduction science, 92(3), 211-230.

Wilmut, I., Beaujean, N., De Sousa, P. A., Dinnyes, A., King, T. J., Paterson, L. A., ... \& Young, L. E. (2002). Somatic cell nuclear transfer. Nature, 419(6907), 583-587. 